\title{
MAKNA FILSAFAT
}

\author{
Andi Arsi $^{1}$,Wa Ode Nurfitri Fail ${ }^{2}$ \\ Dosen Pembimbing:Ibnu Hajar Sainuddin ${ }^{3}$
}

Sekolah Tinggi Agama Islam (STAI) Darul Dakwah Wal-Irsyad (DDI) Kota Makassar, Indonesia Email: arsia3739@gmail.com

Sekolah Tinggi Agama Islam (STAI) Darul Dakwah Wal-Irsyad (DDI) Kota Makassar, Indonesia Email: waodenurfitrifail@gmail.com

Sekolah Tinggi Agama Islam (STAI) Darul Dakwah Wal-Irsyad (DDI) Kota Makassar, Indonesia

Email: Ibnuhajar@staiddimakassar.ac.id

\begin{abstract}
ABSTRAK
Adakah sesuatu yang dinamakan 'filsafat Islam'? Dan jikalau ada, apakah yang dimaksud dengan 'filsafat Islam'? Pertanyaan-pertanyaan ini dan seumpamanya akan coba dijawab dan dibahas secara jernih lagi bernas dengan merujuk kepada sumber-sumber otoritatif dan karya-karya primer sebatas jangkauan penulis. artikel ini akan mengulas definisi dan terminologi filsafat dalam Islam, termasuk makna filsafat.
\end{abstract}

Kata Kunci: Makna,Filsafat ,Islam,

\section{Pendahuluan}

Beberapa dekade terakhir menyaksikan kebangkitan kembali minat terhadap studi filsafat Islam di berbagai belahan dunia. Sementara di sisi lain masih banyak yang bertanya-tanya adakah sesuatu yang dinamakan “filsafat Islam”? Dan jikalau ada, apakah yang dimaksud dengan “filsafat Islam” itu? pertanyaan inilah yang akan coba dijawab dalam tulisan berikut ini.

\section{Makna Filsafat}

Istilah 'filsafat' atau 'falsafah' dalam bahasa Indonesia diserap dari bahasa Arab: فلسفة Ia merupakan pengaraban dari kata majmuk (philosophia) yang dalam bahasa Yunani kuno gabungan dari kata philein (cinta) dan sophia (kearifan). Apa makna “sophia”? Kata Aristoteles: "Biasanya sophia dipahami sebagai pengetahuan mengenai pokok-pokok perkara dan sebab-sebabnya .Para cendekiawan Romawi dan Skolastik abad pertengahan kemudian menerjemahkan "sophia” ke dalam bahasa Latin menjadi “sapientia”, dari kata kerja sapere yang artinya mengetahui. 
Thomas Aquinas menurunkan definisinya: "Sapientia adalah pengetahuan yang membahas sebab sebab utama dan sebab-sebab umum; sapientia meneliti sebab-sebab inti dari segala sebab (sapientia est scientia quae considerat causas primas et universales causas; sapientia causas primas omnium causarum considerat). Pengertian ini dipakai hingga abad kedelapan-belas, dimana Claudius Frassen menulis: "Philosophia dicitur amor sapientiae, et formatur a nominibus Gracis, [amicus], et [sapientia], unde Philosophus is dicendus est, qui studio et assidua animi contentione sapientiam investigat.

Singkatnya, "filsafat” itu ilmu pengetahuan yang dicapai manusia dengan akal pikirannya. Para filsuf/mempelajari aneka persoalan alam semesta, langit, bumi, manusia, hewan, tumbuh-tumbuhan, mineral, dan lain sebagainya. Mereka adalah kelompok orang-orang yang di zaman sekarang kita panggil sebagai saintis. Betul, filsuf adalah saintis, karena waktu itu belum dikenal pemisahan dan pembedaan sempit seperti yang kita kenal saat ini antara filsafat dan sains, antara filsuf dan saintis, antara ahli biologi dan ahli geologi, antara ahli fisika dan ahli kimia. Bahkan hingga zaman Is aac Newton (16421727), kajian mengenai fenomena-fenomena alam yang kini kita namakan "fisika” masih disebut "filsafat alam”.

Simaklah judul karya monumental Newton: Philosophiae naturalis principia mathematica -prinsip-prinsip matematis dari filsafat alam (1687). Adapun istilah "scientia” dan turunannya (science, scienza, sains) dalam arti yang sempit baru marak digunakan sejak dua abad terakhir ini. Walhasil, istilah "filsafat" mengalami pengerucutan arti hingga akhirnya dimaknai tak lebih dari sekadar kajian spekulatif terhadap asal-usul dan pokok-pokok yang mendasari sesuatu. Lalu ketika dihubungkan dengan cabang ilmu tertentu, filsafat kemudian dipahami sebagai perenungan mendalam dan penguraian menyeluruh tentang persoalan-persoalan asasi, prinsip-prinsip, dan hukum hukum dalam ilmu yang bersangkutan.

Muncul istilah filsafat ilmu matematika, filsafat ilmu fisika, filsafat ilmu biologi, filsafat ilmu pendidikan, filsafat ilmu ekonomi, dan lain-lain. Situasi ini bertambah buruk menyusul kampanye anti-metafisika yang dimotori oleh pengusung "logical positivism" alias "logical empiricism” semacam Bertrand Russell, Alfred Jules Ayer, Ludwig Wittgenstein, dan Rudolph Carnap.5 Menurut mereka, filsafat bukanlah ilmu tentang Tuhan, alam, dan manusia yang kini sudah dikapling-kapling menjadi teologi, fisika, biologi, kimia, psikologi, antropologi, sosiologi, ekonomi, dan sebagainya itu. Filsafat uraian logis lagi matematis atas bahasa yang digunakan oleh ilmuwan sebagai medium penyampai pengetahuan. Intisari doktrin mereka tersimpul dalam ungkapan masyhur dari Wittgenstein: "Was sich überhaupt sagen lässt, lässt sich klar sagen; und wovon man nicht reden kann, darüber muss man schweigen”, yang maksudnya apabila sesuatu itu bisa dibicarakan, maka ia mesti bisa dibicarakan dengan jelas, dan karenanya segala sesuatu yang tidak bisa dibicarakan secara jelas semestinya kita diamkan saja.6 Atau dengan kata lain, kalau tidak paham, lebih baik diam. Namun jikapendapat ini kita ikuti, niscaya Plato dan Aristoteles pun tak akan layak disebut filsuf, sebab hanya kaum positivis-logis sajalah yang pantas menyandang gelar filsuf. 


\section{PENUTUP}

Istilah "filsafat" mengalami pengerucutan arti hingga akhirnya dimaknai tak lebih dari sekadar kajian spekulatif terhadap asal-usul dan pokok-pokok yang mendasari sesuatu. Lalu ketika dihubungkan dengan cabang ilmu tertentu, filsafat kemudian dipahami sebagai perenungan mendalam dan penguraian menyeluruh tentang persoalan-persoalan asasi, prinsip-prinsip, dan hukum hukum dalam ilmu yang bersangkutan.

\section{Daftar Pustaka}

‘Abdul Raziq, Mustafa. 1944. Tamhîd li Târîkh al-Falsafah alIslâmiyyah. Kairo

. Adamson, P. dan R.C. Taylor. 2005. The Cambridge Companion to Arabic Philosophy. Cambridge: CUP.

Al-Âmiri. 1988. Kitâb al-Amad alâ al-Abad, Ed. dan Terj. E. Rowson, A Muslim Philosopher on the Soul and Its Fate. New Haven: American Oriental Society.

Aquinas, Thomas. 1926. In Metaphysicam Aristotelis Commentaria, ed. M.-R. Cathala.

Aristoteles. 1980. Ta Meta ta Physika, Terj. H. Tredennick. Cambridge, MA

. Barry S. 1987. Logical Positivism in Perspective: Essays on Language, Truth and Logic, Ed. London: Croom Helm.

Sainuddin, Ibnu Hajar, et al. "Syekh Yusuf Al-Makassari: Pandangan Etika dan Filsafat."

Sainuddin, I. H., Wekke, I. S., Rajjako, A., \& Raya, H. M. I. C. G. Syekh Yusuf Al-Makassari: Pandangan Etika dan Filsafat.

SAINUDDIN, Ibnu Hajar; WEKKE, Ismail Suardi. Syekh Yusuf Al-Makassari: Pandangan Etika dan Filsafat. 2020. 